\title{
Przemysław Michalski*
}

\section{Przebudzenie Kate Chopin, czyli „amerykańska Bovary”(?)}

Gdy w 1899 roku ukazało się Przebudzenie (The Awakening), druga powieść Kate Chopin (1850-1904), jej autorka była postacią dość dobrze znaną w świecie literackim Południa Stanów Zjednoczonych. Zdążyła już opublikować powieść At Fault (1890) oraz szereg opowiadań, które ukazywały się w poczytnych czasopismach i magazynach, takich jak: Vogue, The Century, Youth's Companion, The Atlantic Monthly oraz Harper's Young People, a następnie zostały zebrane w dwóch tomach; pierwszy z nich nosił tytuł Bayou Folk i został wydany w 1894 roku, a drugi, zatytułowany A Night in Acadie, trzy lata później'. Obydwa zostały ciepło przyjęte przez krytyków i czytelników, którzy chwalili autorkę za sprawne odmalowanie lokalnego kolorytu Luizjany, umiejętność uchwycenia charakterystycznych zachowań mieszkańców i wierne odtworzenie ich dialektu. Oprócz tego Chopin, która znakomicie władała językiem francuskim, tłumaczyła opowiadania Guy de Maupassanta. Wpływ tego naturalisty na twórczość pisarki z St. Louis był przedmiotem wielu studiów i analiz ${ }^{2}$. Być może to właśnie zamiłowanie do kultury francuskiej z jej nader swobodnym podejściem do kwestii erotycznych (nie do pomyślenia na konserwatywnym Południu Stanów Zjednoczonych) należy częściowo winić za błędną ocenę rynku wydawniczego i oczekiwań czytelników, którzy zdecydowanie odrzucili drugą powieść autorki. Trudno było jednak przypuszczać, że będzie to punkt zwrotny w jej karierze, a niesłychanie wrogie przyjęcie utworu

* Dr hab., Uniwersytet Pedagogiczny im. KEN w Krakowie, Instytut Neofilologii, ul. Podchorążych 2, 30-084 Kraków, e-mail: przemyslaw.michalski@up.krakow.pl

1 Zob. B. Koloski, The Awakening. The first 100 years, w: The Cambridge Companion to Kate Chopin, red. J. Beer, Cambridge University Press, Cambridge 2008, s. 161.

2 Zob. na przykład: E. Nolan, The Awakening as literary innovation: Chopin, Maupassant and the evolution of genre, w: The Cambridge Companion to Kate Chopin..., s. 118-131; R. Fusco, Maupassant and the American Short Story: The Influence of Form at the Turn of the Century, Pennsylvania State University Press, University Park, PA 1994. 
sprawi, że Chopin napisze już bardzo niewiele, do czego przyczyniło się również rozwiązanie umowy wydawniczej na kolejny zbiór opowiadań, jak również podupadające zdrowie pisarki ${ }^{3}$. Biografowie Kate Chopin ustalili, że powieść powstała pomiędzy czerwcem 1897 a styczniem $1898^{4}$. Jej pierwotny tytuł to A Solitary Soul, czyli „samotna dusza”. Zarówno ten tytuł, jak i późniejszy, już sugerują pewne bowarystyczne tropy interpretacyjne, chętnie podejmowane przez komentatorów ${ }^{5}$.

Jak wspomniano wcześniej, reakcja krytyki była prawie całkowicie nieprzychylna. Większość recenzentów doceniła co prawda znakomity warsztat powieściopisarki, jednak ich oburzenie miało przede wszystkim charakter moralny. Podobnie jak Gustaw Flaubert ponad 40 lat wcześniej, Chopin popełniła niewybaczalną (wedle ówczesnych kryteriów) zbrodnię: przedstawiła portret kobiety, która budzi się do możliwości całkowitej niezależności, odrzuca obowiązujący ideał kobiecości (tzw. wiktoriański model Angel in the House, a więc kobiety biernej, posłusznej, gotowej do poświęceń, całkowicie oddanej małżeństwu i macierzyństwu) i - podobnie jak Emma Bovary - szuka erotycznego spełnienia poza łożem małżeńskim. Co więcej, podobnie jak bohaterka Flauberta, chopinowska Edna Pontellier kończy życie samobójstwem. Poza tym, recenzenci i krytycy nie mogli wybaczyć autorce tego, że próżno by szukać w powieści słów jednoznacznego napiętnowania takiego postępowania. Co prawda Kate Chopin przewrotnie przyznała w lipcu 1899 na łamach Book News, że „nigdy nie przypuszczała, że

3 Zob. E. Toth, What we do and don't know about Chopin's life, w: The Cambridge Companion to Kate Chopin..., s. 24.

4 Zob. M.E. Papke, Kate Chopin's Social Fiction, w: Kate Chopin, red. H. Bloom, Ch. House Publishers, Langhorne 2007, s. 58.

5 Za Anetą Mazur definiuję bowaryzm jako amalgamat określonych cech osobowościowych oraz rozwiązań fabularnych, które prowadzą do finalnej tragedii. Składają się na nań „małżeńskie rozczarowanie i zdrada, wyalienowanie z codzienności i znudzenie, pragnienie ucieczki od prozy życia, zdeterminowane (melodramatycznymi) schematami literackiej proweniencji, głód zmysłowych i nastrojowych wrażeń, jak również ironiczna, odautorska demaskacja żałosnej tragikomedii życia" (A. Mazur, Nowelistyczny tryptyk Stefanii Chłędowskiej - zagubione ogniwo polskiego „bowaryzmu”?, „Pamiętnik Literacki” R. 103: 2012, z. 4, s. 30). Autorka proponuje również ciekawą analogię między Edną Pontellier oraz Amelią z rzadko dziś czytanej noweli Stefanii Chłędowskiej Babie lato: „Amelia bowiem to kreacja pokrewna jednej z literackich sióstr pani Bovary: bohaterce sztandarowej, feministycznej powieści Kate Chopin Przebudzenie z roku 1889. Podobnie jak Amerykanka Edna, heroina Chłędowskiej jest ubezwłasnowolnioną, potulną małżonką tudzież matką kilku synów. Po raz pierwszy opuszcza zaborczy klan rodziny męża i podczas kuracji spędzając całe dnie na powietrzu, chłonie niczym Edna nowe impulsy oraz wrażenia. I jak tamta rodzi się do nowego życia - świadomej kobiecości" (s. 41). Jeśli chodzi o recepcję Pani Bovary w Polsce, zob: B. Mazan, Literackie transpozycje doświadczenia bowarystowskiego w miłości, w: Sztuka a erotyka, red. T. Hrankowska, Stowarzyszenie Historyków Sztuki, Warszawa 1995, s. 35-47. 
Edna tak straszliwie wszystko sknoci”, trudno jednak uznać te przekorne quasi-przeprosiny za wyrazy rzeczywistego potępienia. Nie zabrakło ich za to w miażdżących na ogół recenzjach.

I tak na przykład Frances Porcher w magazynie The Mirror wyraził żal z powodu niewczesnego „przebudzenia” bohaterki, które uświadamia czytelnikowi, jakim „szpetnym, okrutnym i ohydnym potworem potrafi okazać się Namiętność" (The Mirror: 4 V 1889) Według anonimowego recenzenta z Globe Democrat, lokalnej gazety z St. Louis, Przebudzenie to "nie jest zdrowa książka”, jest to wręcz książka „chorobliwa” [morbid]. Inni komentatorzy ubolewali nad potencjalnym wpływem podobnych opowieści na moralność młodzieży; historie takie, jak ta opisana w Przebudzeniu, „podsuwają grzeszne wyobrażenia i nieczyste żądze” oraz mogą sprawić, iż młodzi ludzie zaczną „rozmyślać o rzeczach, które jedynie osoby dorosłe mogą zrozumieć" (Sunday Journal: 4 VI 1899). Jeszcze dalej posunął się recenzent Public Opinion, według którego „odczuwamy satysfakcję, kiedy pani Pontellier celowo wypływa na spotkanie śmierci" (Public Opinion: 22 VI 1899). Niektórzy żałowali, iż tak znakomity styl został zmarnowany na "tak bardzo wulgarną opowieść" (Literature: 23 VI 1899). Nawet nieliczne pozytywne recenzje, jak np. pióra C.L. Deyo, ostrzegały czytelników, że Przebudzenie to książka jedynie dla „wyrobionych dusz" [seasoned souls] (Post-Dispatch: $20 \mathrm{~V} \mathrm{1899)7.}$

Co istotniejsze dla niniejszych rozważań, od samego początku pojawiały się porównania powieści Chopin z Panią Bovary. Recenzentka występująca pod pseudonimem „Silbert” (pod którym ukrywała się powieściopisarka Willa Cather) nazwała Przebudzenie „kreolską Bovary”, choć - jak złośliwie dodaje - nie znaczy to wcale, że „pani Chopin jest Flaubertem”. Według niej:

Edna Pontellier i Emma Bovary to dwa studia tego samego typu kobiety; jedno z nich jest skończonym portretem, drugie ledwie pospiesznym szkicem, ale łączy je podobny temat. Obie kobiety należą do tej samej klasy ludzi, [...] domagających się od życia więcej romansu, niż Bóg raczył mu przydać.

6 Warto przytoczyć tę błyskotliwą wypowiedź w całości: "Having a group of people at my disposal, I thought it might be entertaining (to myself) to throw them together and see what would happen. I never dreamed of Mrs. Pontellier making such a mess of things and working out her own damnation as she did. If I had had the slightest intimation of such a thing I would have excluded her from the company. But when I found out what she was up to, the play was half over and it was too late". Cyt. za: N.A. Walker, Introduction: Biographical and Historical Contexts, w: The Awakening: Complete, Authoritative Text With Biographical \& Historical Contexts, Critical History, \& Essays from Five Contemporary Critical Perspectives, red. N.A. Walker, Bedford/St Martins, Boston 1993. s. 14. O ile nie zaznaczono inaczej, wszystkie tłumaczenia z cytowanych tekstów anglojęzycznych mojego autorstwa (P. M.).

7 Wszystkie cytaty z przytoczonych recenzji pochodzą ze strony internetowej: http://www. people.virginia.edu/ sfr/enam854/summer/awcritf.html [dostęp 20.08.2017]. 
Recenzja utrzymana jest $\mathrm{w}$ sardonicznym tonie, a prowokacyjnie nieszczere współczucie wobec obu „biednych kobiet” ma jedynie uwydatnić ich intelektualną miałkość oraz chorobliwą podatność na podszepty namiętności. Kobiety tego typu:

płacą własną krwią za piękne ideały poetów. [...] Spodziewają się, że namiętność wypełni i zaspokoi wszelakie, nawet najmniejsze, potrzeby życiowe, podczas gdy natura chce, aby służyła one jedynie do zaspokojenia jednej z wielu potrzeb. [...] Pragną życia przypominającego dramaty Szekspira lub powieści Balzaka. Stawiają wszystko na jedną kartę i nieuchronnie przegrywają.

Na końcu recenzentka wyraża nadzieję, że „następnym razem pani Chopin znajdzie lepszy temat dla swojego giętkiego i błyskotliwego stylu".

Niestety, następnego razu miało już nie być. Po skrajnie nieprzychylnym przyjęciu Przebudzenia, Kate Chopin praktycznie przestała pisać i publikować, a samą powieść otoczyła prawie kompletna cisza. Co prawda Przebudzenie zostało wydane jeszcze raz w roku 1906, ale wydarzenie to przeszło bez echa. Zresztą zapomnienie dotknęło również samą autorkę. Bardzo nieliczne recenzje były nadal utrzymane $\mathrm{w}$ negatywnym tonie ${ }^{8}$. Nie udało się jednak biografom potwierdzić często powtarzanej informacji o usunięciu Przebudzenia z bibliotek w jej rodzinnym St. Louis?

Bez wątpienia najważniejszym wydarzeniem, przynajmniej na chwilę przerywającym pośmiertne zapomnienie pisarki, było ukazanie się pierwszej biografii Chopin w roku 1932. Jej autorem był Daniel Rankin, który miał tę przewagę nad późniejszymi badaczami jej życia i twórczości, że mógł nawiązać kontakt z osobami jeszcze pamiętającymi pisarkę. Choć biografia jego autorstwa jest pełna wyrazów uznania dla talentu Kate Chopin, ani temperament, ani profesja Rankina, który był katolicki księdzem, nie pozwoliły mu na docenienie odwagi i oryginalności Przebudzenia. Kiedy Rankin o nim pisze, pomija czysto literackie wartości powieści, natomiast jego oburzenie wywołuje postępowanie głównej bohaterki. Widzimy w tych fragmentach biografii, jak moralista potępiający powieść z punktu widzenia nauki etycznej swojego Kościoła zajmuje miejsce bezstronnego badacza literatury, który wcześniej docenił jednak kunszt opowiadań Chopin. Tak więc trzydzieści trzy lata po ukazaniu się powieści Edna Pontellier zostaje po raz kolejny uznana za persona non grata w świecie literatury amerykańskiej ${ }^{10}$.

Dopiero po drugiej wojnie światowej nastąpił renesans zainteresowania skandalizującą powieścią. Cyrille Arnavon nie tylko przełożył Przebudzenie na francuski, ale również porównał do słynnego dzieła Flauberta, nazywając jej główną

8 Np. Percival Pollard w roku 1909 odrzucił powieść jako „mało wiarygodną". Percival Pollard, Their Day in Court, Neale, New York 1909, s. 40.

9 E. Toth, dz. cyt., s. 24.

10 B. Koloski, dz. cyt., s. 164. 
bohaterkę „amerykańską Bovary”"1. Pojawiły się też akademickie analizy, które (w przeciwieństwie do recenzji z przełomu wieków) w mniejszym stopniu interesowały się moralną oceną czynów Edny Pontellier, a bardziej zwracały uwagę na wysokie walory formalne powieści, na umiejętne zarysowanie postaci, ujmujący i elegancki język utworu, zapadający w pamięć portret kobiety budzącej się do świadomości swej odrębności oraz inne zalety tekstu. I tak na przykład w roku 1956 Kenneth Eble pisał z uznaniem o Przebudzeniu, które „dzisiaj nikogo już nie razi”, nazywając je równocześnie „zapomnianą powieścią”"12. Aby je z tego zapomnienia wydobyć, zajął się opracowaniem taniego wydania (tzw. paperback, czyli niedroga edycja w miękkiej oprawie). Krytycy i badacze literatury, tacy jak: Rober Cantwell, Edmund Wilson, Warner Berthoff i Larzer Ziff, również zachęcali do ponownej lektury niesłusznie zapomnianego arcydzieła.

Jednym z kamieni milowych w historii recepcji twórczości Kate Chopin była monumentalna edycja dzieł powieściopisarki opracowana przez norweskiego badacza Pera Seyersteda (Complete Works of Kate Chopin, 1969) oraz wydana jedenaście lat później biografia (A Critical Biography). Jedną z największych zasług komentarza Seyersteda jest umieszczenie dzieła Chopin w kontekście literatury amerykańskiej oraz światowej. Jednocześnie dowodzi on, że na tle całego dorobku Chopin, Przebudzenie nie jawi się bynajmniej jako nieszczęśliwy „wypadek przy pracy”, lecz jest wynikiem naturalnej ewolucji jej stylu i światopoglądu. Norweski badacz widzi Chopin jako ważny głos w tradycji powieści realistycznej, wskazując na wiele pionierskich cech jej dzieła. Poświęca też nieco miejsca na omówienie podobieństw między Przebudzeniem a Pania Bovary, przy okazji udowadniając, że Chopin czytała Flauberta w oryginale ${ }^{13}$. Praca Seyersteda uświadomiła Amerykanom, że przez wiele lat podręczniki literatury pomijały wybitną powieść i czas najwyższy, aby to niedopatrzenie nadrobić. W rezultacie ukazało się wiele wydań Przebudzenia, nastąpiła również prawdziwa eksplozja akademickiego zainteresowania twórczością pisarki z Luizjany ${ }^{14}$.

11 C. Arnavon, Introduction to Kate Chopin, Edna (1953), tłum. B. Braaten i E. Toth, w: The Kate Chopin Miscellany, red. P. Seyersted i E. Toth, Northwestern University Press, Natchitoches, LA 1979, s. 181. Zob. też: The Awakening: Sourcebook, red. J. Beer i E. Nolan, Routledge, London 2007, s. 53.

12 B. Koloski, dz. cyt., s. 164; N. Walker, A Critical History of The Awakening, w: Kate Chopin. The Awakening..., s. 141.

13 P. Seyersted, Kate Chopin: A Critical Biography, Louisiana State University Press, Baton Rouge 1980, s. 86; zob. też: N. Walker, dz. cyt., s. 153.

14 Już nie pojedyncze artykuły, lecz całe książki podejmowały problematykę licznych opowiadań i dwóch powieści Kate Chopin, na przykład: P. Skaggs, Kate Chopin, Twayne Publishers, Woodbridge 1985; B.C. Ewell, Kate Chopin, Ungar Publishing Company, New York 1986; B. Koloski, Kate Chopin: A Study of the Short Fiction, Twayne Publishers, Woodbridge 1996. Ciekawą pozycją jest The Kate Chopin Companion opracowany przez Thomasa Bonnera, który przynosi 
Lata siedemdziesiąte i osiemdziesiąte to okres gwałtownego rozwoju rozważań teoretycznych i proliferacji różnorakich (nieraz silnie zideologizowanych) filtrów, przez które można odczytywać teksty literackie. Nic dziwnego, że powieść Kate Chopin również doczekała się wielu interpretacji. Pojawiły się analizy psychoanalityczne, marksistowskie, strukturalistyczne, lacanowskie, dekonstrukcjonistyczne, postkolonialne, itp. Jednak najważniejsze interpretacje, które do dzisiaj stanowią znaczną część krytycznych opracowań utworu, to odczytania feministyczne. Odrzucając przestarzałe poglądy na literaturę z przełomu XIX i XX w., które potępiły powieść ze względu na jej rzekomą niemoralność, bojowniczki o równouprawnienie płci zobaczyły w Ednie nie upadłą kobietę oraz zaprzeczenie ideału matczynej miłości, lecz odważną proto-feministkę, zniszczoną przez bezwzględne siły starego porządku. Według odczytań feministycznych jej samobójcza śmierć to nie tylko desperacka próba wyzwolenia od patriarchalnego ucisku, ale również ofiara złożona na ołtarzu walki o godność kobiety.

Wzrost zainteresowania twórczością Kate Chopin przyniósł również nowe biografie pisarki z Luizjany. Co ciekawe, oba studia biograficzne są autorstwa tej samej badaczki - Emily Toth. Pierwsze pochodzi z roku 1990, a następne, zatytułowane Unveiling Kate Chopin, zostało opublikowane dziewięć lat później (czyli w setną rocznicę ukazania się Przebudzenia) i od poprzedniczki różni je przede wszystkim bardziej osobisty charakter. W podobnie intymnym tonie utrzymany jest zbiór esejów cenionych znawców twórczości Kate Chopin, pt. Awakenings, czyli „przebudzenia”. Składa się z tekstów-wyznań, które celowo porzucają bezosobowy warsztat krytyki literackiej, zamiast tego opowiadając o wpływie, jaki powieść Kate Chopin wywarła na wybory życiowe ich autorów ${ }^{15}$. Dzisiaj Przebudzenie często trafia na listy lektur, ciągle na nowo inspirując studentów i naukowców. Można powiedzieć, że po wielu latach Edna Pontellier zajęła poczesne miejsce w panteonie kobiecych postaci literatury anglojęzycznej, zapewne gdzieś obok Hester Prynne ze Szkarłatnej litery Nathaniela Hawthorne’a, Izabeli Archer z Portretu damy Henry'ego Jamesa oraz Jane Eyre ze słynnej powieści Emily Brontë.

Najwyższy czas powrócić jednak do kwestii bowaryzmu Przebudzenia. Jak już wcześniej zaznaczono, powieść Kate Chopin określa się nieraz za Arnavonem mianem „amerykańskiej Bovary”. Na podobieństwa wskazywała jedna z pierwszych recenzji, przytoczona na początku niniejszego artykułu; wspominał o nich również Per Seyersted oraz wielu innych badaczy. Jednym z nich jest Susan J. Rosowski, która w studium o wyraźnie feministycznym charakterze porównuje powieści Flauberta i Chopin, su-

opisy 900 postaci i 200 miejsc z jej opowiadań. Warto też wspomnieć o edycji Nortona, która oprócz samej powieści zawiera aż dwadzieścia siedem krytycznych analiz tekstu (K. Chopin, The Awakening, Norton Critical Editions, red. M. Culley, W.W. Norton \& Company 1993). 
gerując, że główną odpowiedzialność za tragiczne losy Emmy Bovary i Edny Pontellier ponosi zdominowane przez patriarchalne struktury społeczeństwo ${ }^{16}$.

W roku 1994 także profesor Stephen Heath z Uniwersytetu Cambridge podniósł na nowo problem bowaryzmu Przebudzenia. Według angielskiego badacza powieść Chopin:

przepisuje i przemienia Panią Bovary. [...] Emma Bovary staje się Edną Pontellier i po raz kolejny, doświadczywszy znużenia małżeństwem i poznawszy namiętność cudzołóstwa, zamężna kobieta sięga po samobójstwo ${ }^{17}$.

Co ciekawe, Heath porównuje też postacie męskie obu powieści, wskazując na istotne podobieństwa zarówno w ogólnym rysunku bohaterów, jak i konkretnych rozwiązaniach fabularnych. Rzeczywiście, rzuca się w oczy pewna symetria w budowaniu postaci męskich: zarówno poczciwy Karol z powieści Flauberta, jak i przyziemny Léonce z Przebudzenia, nie dostrzegają niewierności swych żon. Co więcej, żaden z nich nie tylko nie jest świadomy potrzeb erotycznych żony, ale nawet samego faktu istnienia kobiecej seksualności. Jednak Léonce to słabo zarysowana, wyraźnie antypatyczna i jednowymiarowa postać, podczas gdy Karol to raczej dobroduszny nieudacznik i zdradzany mąż, w stosunku do którego wielu czytelników odczuwa współczucie. Z drugiej strony, obaj patrzą na swe żony w sposób bardzo konwencjonalny, to znaczy traktują je przede wszystkim jako elementy dekoracyjne, nie dostrzegając zupełnie ich głębszych (i bardziej biologicznych) potrzeb ${ }^{18}$.

Podobni są również młodzieńcy pojawiający się w obu powieściach: Leon z Pani Bovary i Robert z Przebudzenia. Obaj wydają się pełni romantyzmu i niewinności, obaj też okazują się pod koniec powieści dalecy od ideału. Leon staje się cynicznym uwodzicielem, który łatwo poddaje się złudnym urokom paryskiego życia, a Robert człowiekiem o ciasnych patriarchalnych poglądach, wedle których to mężczyzna jest panem i władcą kobiety ${ }^{19}$. Natomiast notoryczny uwodziciel Alcée Arobin z Przebudzenia to wręcz lustrzane odbicie Rudolfa z Pani Bovary; dla obu miłość

16 S.J. Rosowski, The Novel of Awakening, "Genre", nr 12, 1979, s. 313-332.

17 S. Heath, Chopin's Parrot, "Textual Practice", nr 8 (1), wiosna 1994, s. 12.

18 Jest to widoczne już w pierwszej scenie Przebudzenia, w której mąż Edny krytykuje ją za nadmierną opaleniznę: „Opaliłaś się, że trudno cię poznać - dodał patrząc na żonę, jak się patrzy na cenną własność, która doznała pewnego uszczerbku" (K. Chopin, Przebudzenie, tłum.

A. Demkowska-Bohdziewicz, Libros, Warszawa 2002, s. 3).

19 W rozdziale 36 Robert żałuje, że nie może być razem z Edną, gdyż należy ona do innego mężczyzny. Urażona Edna odpowiada: „Tracisz czas na marzenie o rzeczach niemożliwych, myśląc, że pan Pontellier mógłby zwrócić mi wolność! Nie jestem już jego własnością, z której może zrezygnować albo nie. Oddaję się temu, kogo sama wybiorę. Gdyby on ci powiedział: „Robercie, bierz ją sobie i bądź szczęśliwy, jest twoja” - to wyśmiałabym was obydwóch". Robert jest wyraźnie zaszokowany tym wyznaniem. 
jest jedynie ekscytującą grą, a kobieta instrumentem służącym zaspokojeniu erotycznych potrzeb mężczyzny ${ }^{20}$. Podobne są wreszcie konkretne rozwiązania fabularne, na przykład ucieczka Rudolfa i Roberta, którzy żegnają się z opuszczaną kobietą za pomocą krótkiej notatki.

Według moich ustaleń, najnowszym głosem w tej dyskusji jest artykuł „Abysses of Solitude": Chopin's Intertextuality with Flaubert, którego autorem jest Jean Witherow z Louisiana State University ${ }^{21}$. Autorka koncentruje się na języku i stylu obu powieści, dowodząc, że o ile dzieło Flauberta jest tekstem o charakterze stricte realistycznym, Przebudzenie należałoby raczej uznać za powieść inspirowaną naturalizmem. W przeciwieństwie do francuskiego pisarza, Kate Chopin chętniej używa też symbolizmu, podczas gdy dla Flauberta przedmioty opisane w powieści nie mają sugerować abstrakcyjnych jakości, lecz stanowią tło lingwistycznej sceny, na której rozgrywa się dramat. Co prawda symbolizm Przebudzenia często bywa wysoce ironiczny i w subwersywny sposób posługuje się banalnymi metaforami, aby - tu można odnaleźć kolejne podobieństwo z Panią Bovary - wykpić romantyczne mrzonki i sentymentalne rojenia ${ }^{22}$. Witherow zwraca też uwagę na wyraźne różnice w stosunku narratora do wykreowanych postaci: u Flauberta narrator pozostaje obiektywny i bezosobowy, relacjonuje kolejne zdarzenia z bezstronnością profesjonalnego naukowca, w Przebudzeniu natomiast można wyczuć wyraźną sympatię narratora (narratorki) dla Edny, choć nie znaczy to wcale, że Chopin ją idealizuje; przeciwnie, ta sympatia jest nieustannie modyfikowana kontrapunktem łagodnej ironii ${ }^{23}$.

Oczywiście najbardziej istotne analogie dotyczą głównych bohaterek powieści: Emmy Bovary i Edny Pontellier (zapewne fonetyczna zbieżność ich imion również nie jest przypadkowa). Dotykają one zarówno ich losów, jak i specyficznej konstytucji psychicznej obu kobiet. Stephen Heath twierdzi, że w ich zachowaniu da się zauważyć niemal identyczne symptomy; podobnie jak Emma, Edna:

płacze bez powodu, cierpi na zawroty głowy i ataki duszności, jest emocjonalnie nadwrażliwa, odczuwa «nieopisane przygnębienie» i «nieokreślony lęk», a w życiu rodzinnym dostrzega jedynie przerażającą i beznadziejną nudę [ennui ${ }^{24}$.

Kolejna paralela to stosunek obu kobiet do własnych dzieci. Tak jak Emma, Edna zdecydowanie (choć na początku swego przebudzenia raczej instynktownie

20 S. Heath, dz. cyt., s. 18-19.

21 J. Witherow, "Abysses of Solitude": Chopin's Intertextuality with Flaubert, "The Mississippi Quarterly," nr 64, 1-2, wiosna 2011, s. 87-107.

22 Zob. K. Wheeler, Kate Chopin: Ironist of Realism, w: Kate Chopin, s. 119-144.

23 Ciekawym przykładem takiego subtelnego użycia ironii jest scena, w której Edna czyta Emersona - duchowego ojca amerykańskiego ideału niezależności. Niestety, zasypia podczas lektury.

24 S. Heath, dz. cyt., s. 13. 
niż świadomie) odrzuca obowiązujący wówczas ideał, nakazujący kobiecie gotowość do nieograniczonych poświęceń na rzecz potomstwa. Pozornie obiektywny, a w rzeczywistości pełen subtelnej ironii i sympatii, komentarz odautorski już w początkowych rozdziałach informuje czytelnika, że Edna nie znajdzie spełnienia w macierzyństwie, gdyż przeczuwa, że może być ono osiągnięte jedynie za cenę rezygnacji z możliwości samorealizacji:

Kobiety-matki zdawały się przeważać tego lata na Grand Isle. Łatwo można je było rozpoznać - krążące z opiekuńczo rozpostartymi skrzydłami, gdy tylko jakieś niebezpieczeństwo, prawdziwe lub wyimaginowane, zagrażało ich cennemu potomstwu. Były to kobiety, które ubóstwiały swe dzieci, czciły swych mężów i uważały za święty przywilej wyzbycie się wszelkiej indywidualności w zamian za skrzydła anioła stróża"25.

Myślnik łączący rzeczowniki „matka” i „kobieta” sugeruje nierozłączność, a nawet synonimiczność: być kobietą to być matką. Taką postacią jest w powieści (skądinąd podziwiana przez Ednę) Adèle Ratignolle, która znajduje spełnienie w macierzyństwie i życiu rodzinnym. Jednak Edna będzie próbowała te dwa rzeczowniki rozdzielić i przyznać pierwszeństwo potrzebom kobiety nad instynktami matki, ściągając na siebie powszechne potępienie, podobnie jak wydanie powieści ściągnęło potępienie na jej autorkę.

Ponieważ Edna jest tak ciekawą i wielowymiarową postacią, przez większą część powieści czytelnik kibicuje bohaterce czy wręcz utożsamia się z jej postępowaniem. $Z$ drugiej strony, nie wolno pominąć subtelnie naszkicowanej dwuznaczności i delikatnej drwiny narracji, które w ciekawy sposób komplikują nazbyt jednoznaczne interpretacje. Sympatia czytelnika zostaje wystawiona na ciężką próbę, kiedy pod koniec powieści Edna (która najczęściej zleca zajmowanie się swoimi dwoma synami służącym i piastunkom) przyznaje: „Dzieci jawiły się jej jako istoty wrogie [adversaries] i napastliwe, którym uległa pokonana, które usiłowały zapanować na zawsze nad jej duszą"26. A więc to nie bezduszne mechanizmy patriarchalnego społeczeństwa uniemożliwiają Ednie osiągnięcie absolutnej wolności, lecz konieczność poświęcenia cząstki swej niezależności na wychowanie dzieci. Również Emmie Bovary często wydaje się, że jej córka (którą matka widuje nader rzadko) stoi na drodze do realizacji romantycznych fantazji. Pod koniec powieści Edna zostaje pouczona przez Adèle Ratignolle, która przeczuwa, że Edna jest gotowa rozerwać wszelkie więzy łączące ją z dotychczasowym życiem: „Pomyśl o dzieciach, Edno. Pamiętaj o dzieciach! Na Boga, pamiętaj o nich!”27. Tę

25 K. Chopin, Przebudzenie..., s. 9.

26 Tamże, s. 133.

27 Tamże, s. 137. 
przestrogę, jak również późniejsze samobójstwo Edny, należy odczytać w świetle wcześniejszej rozmowy z panią Ratignolle, podczas której Edna szczerze wyznaje, iż macierzyństwo jest dla niej raczej ciężarem niż błogosławieństwem: „Potrafię zrezygnować z tego, co nie jest ważne; mogę oddać pieniądze, mogę oddać życie dla dzieci, lecz nie zrezygnuję z siebie"28. Być może Edna nie jest jeszcze tego do końca świadoma (jak sama mówi: „Nie umiem tego powiedzieć jaśniej, chodzi o coś, co dopiero zaczynam sobie uświadamiać, co się dopiero przede mną samą odsłania"29), ale $\mathrm{w}$ jej przekonaniu istnieje nieusuwalne napięcie między wiernością sobie oraz obowiązkami macierzyńskimi ${ }^{30}$. Na tym polega tragiczna ironia zakończenia powieści: Edna rzeczywiście poświęca życie, ale nie „za” swoje dzieci, ale po to, aby się ostatecznie od tych „wrogich istot” ostatecznie uwolnić. Odrzuciwszy wszelkie ograniczenia na drodze do niejasno zdefiniowanej samorealizacji, poprzez samobójczą śmierć Edna przekracza kolejne tabu i wybiera to, co dla niej najważniejsze, czyli absolutną wolność, nawet jeśli ceną za nią jest fizyczne unicestwienie ${ }^{31}$.

To właśnie kwestia samobójstwa, która na pierwszy rzut oka tak bardzo zbliża losy Emmy i Edny, do dziś dzieli czytelników i interpretatorów powieści. Literatura przedmiotu jest równie bogata, jak ogromny jest diapazon różnorakich odczytań. Próżno by szukać w tekście Flauberta jakiegokolwiek moralizatorstwa, jednak na pewnym poziomie jego słynna powieść jest ostrzeżeniem przed zgubnymi skutkami utożsamienia romantycznych wizji z rzeczywistością (przypomina pod tym względem nieco Portret Doriana Graya Oscara Wilde’a, który również został oskarżony o obrazę moralności). Samobójcza śmierć Emmy jest niewątpliwie przypomnieniem, że w świecie poddanym bezlitosnym prawom natury występny czyn (przy czym owa występność nie jest normą występującą spontanicznie w naturze, lecz spetryfikowanym konwenansem, który uzyskał pozór obiektywności) pociąga za sobą określone konsekwencje. Samobójcza śmierć Edny jest bardziej

28 Tamże, s. 53.

29 Tamże, s. 53.

30 Trudno nie przyznać racji cytowanej już wcześniej recenzji pióra C.L. Deyo, która złośliwie zauważa, że Edna „była gotowa umrzeć za swoje dzieci, ale nie zrezygnować z siebie. To brzmiało błyskotliwie, bo było paradoksem, ale Edna nie bardzo wiedziała, co to znaczy" (Post-Dispatch: 20 May 1899).

31 W ważnej rozmowie z doktorem Mandelet Edna wyznaje: „Nachodzą mnie takie chwile, że ulegam wielkiemu przygnębieniu i cierpię. Ale chcę tylko jednego - chcę żyć po swojemu. To niemało, oczywiście, zwłaszcza gdy trzeba podeptać cudze życie, czyjeś serce, ludzkie przesądy - ale dla mnie to nieważne, chociaż nie chciałabym zniszczyć życia moim dzieciom" (s. 129). W przeciwieństwie do Pani Bovary, gdzie znajdujemy przejmujące opisy cierpienia Karola po śmierci żony, Przebudzenie kończy się sceną samobójstwa Edny w morskich odmętach. Co dzieje się dalej nie wiadomo, ale nietrudno domyślić się jakim wstrząsem dla dzieci musi być samobójcza śmierć matki. Zob. J. Berman, Romanticizing Suicide in Kate Chopin's Awakening w: Surviving Literary Suicide, University of Massachusetts Press, Amherst 1999, s. 61. 
wieloznaczna. Jak już powiedziano wcześniej, odczytania o orientacji feministycznej chciałyby w niej widzieć tragiczne zwycięstwo zrealizowanej wolności - przebudzona kobieta w dramatyczny sposób odmawia powrotu do odgrywania roli posłusznej żony i troskliwej matki. Trudno jednak uznać samobójstwo za gest triumfu. Edna wie, że nie ma dla niej powrotu do poprzedniego życia - lecz można też zobaczyć w jej samobójstwie wyraz najwyższego egoizmu; wybiera raczej nieistnienie niż życie na zasadach, których nie może w pełni sama określić.

Oczywiście fakt, iż ta śmierć następuje w morzu, którego głos „uwodzi, nigdy nie milknie, szumi, skarży się, szepcze, nęci duszę do wędrówki w bezmiar samotności" ${ }^{32}$, ma symboliczne znaczenie. W jednym z początkowych rozdziałów Edna po raz pierwszy w życiu sama pływa w morzu i to niesłychanie ekscytujące zdarzenie uświadamia jej możliwość całkowitej samodzielności. Emancypacyjny wydźwięk opisu jest bardzo wyraźny:

Doznała uczucia nieograniczonej mocy panowania nad własnym ciałem i duszą. Wstąpiła w nią odwaga, a nawet zuchwałość i przeceniając własne siły zapragnęła popłynąć daleko, dokąd jeszcze żadna kobieta nigdy nie dotarła ${ }^{33}$.

Można by więc końcowe wypłynięcie Edny w morze odczytać jako ostateczne (choć tragiczne w skutkach) zwycięstwo wyzwolonej kobiety, trzeba by jednak zignorować obecność innej symboliki. Przebudzenie w interesujący sposób wygrywa napięcie dwóch porządków symbolicznych; można by je nazwać „wodnym” oraz „ptasim”. Ten pierwszy zazwyczaj sygnalizuje możliwość nieskrępowanej wolności lub obietnicę erotycznego spełnienia ${ }^{34}$. Symbolika „ptasia” pojawia się już na pierwszej stronie w postaci papugi, która (podobnie jak Edna) posługuje się językiem „nie znany[m] nikomu” - a potem powraca wielokrotnie w trakcie powieści, na przykład w rozmowie Edny z Panią Reisz, samotną, nieatrakcyjną i nielubianą pianistką, której bezkompromisowa droga życiowa symbolizuje całkowite poświęcenie się sztuce ${ }^{35}$. Podczas rozmowy z Edną ta ekscentryczna kobieta dotyka jej pleców, jak gdyby próbując ocenić siłę niewidzialnych skrzydeł. Metaforyczny wydźwięk jej słów jest oczywisty: „Ptak, który pragnie wzbić się ponad niziny tradycji i przesądów, musi mieć mocne skrzydła. Żałosny to widok, gdy kaleczone i wyczerpane pisklę wraca na ziemię"36. Ta metafora jest jednocześnie zapowiedzią sceny

32 K. Chopin, Przebudzenie..., s. 133.

33 Tamże, s. 30-31.

34 Na temat symbolicznej roli morza w powieści, zob. A. Heilmann, The Awakening and New Woman fiction, w: The Cambridge Companion to Kate Chopin, s. 100 oraz: E. Nolan, dz. cyt., s. 124-125.

35 Zresztą przez pewien czas Edna odczuwa pokusę, aby również szukać samorealizacji poprzez sztukę, nie ma jednak ani talentu, ani odpowiedniej wytrwałości, żeby wprowadzić swój zamiar w czyn. 36 K. Chopin, Przebudzenie..., s. 93. 
samobójstwa, podczas której Edna widzi, jak „[j]akiś ptak ze złamanym skrzydłem bezradnie usiłował wzbić się w górę, lecz trzepocząc i krążąc w powietrzu opadał coraz niżej i niżej nad wodę"37. Najbardziej narzucające się odczytanie tego trywialnego obrazu to ujrzenie w ptaku ze złamanym skrzydłem symbolu ambitnej kobiety, wzlatującej ku wolności, lecz bezlitośnie strąconej przez wrogie siły ${ }^{38}$. Nie jest jednak jasne (i ta dwuznaczność jest jedną z bardziej interesujących cech powieści), czy samobójstwo Edny należy odczytać jako oskarżenie patriarchalnych struktur społecznych, które odbierają kobietom możliwość twórczości artystycznej i społecznej niezależności, czy jest to raczej oskarżenie samej bohaterki, która błędnie utożsamia możliwość niezawisłości z totalnym egoizmem.

Na tym też polega inna ważna różnica między Emmą i Edną; tę pierwszą pochłania bez reszty świat romansu, jest gotowa odrzucić wszystkie zasady i podeptać

37 Tamże, s. 133.

38 Prawie każde zdania tego słynnego zakończenia zostało opatrzone mnóstwem komentarzy. I tak na przykład Ann Heilmann twierdzi, że „oczywiście w czysto realistycznym sensie, Edna zaraz popłynie na spotkanie śmierci, jednak w porządku symbolicznym odnosi zwycięstwo nad swym położeniem [...], gdyż uwalnia się z patriarchalnych struktur małżeństwa" (A. Heilmann, dz. cyt., s. 101). Co ciekawe, autorka zestawia Ednę nie tylko z Emmą Bovary, ale również Anną Kareniną, Edną z The Doctor's Wife Mary Braddon, oraz Effie Briest z powieści Theodora Fontane'a (s. 89). Judith Fryer pisze, że „Edna wybiera śmierć, gdyż jest to jedyny całkowicie wolny czyn, jaki jest dla niej możliwy" (Judith Fryer, The Faces of Eve: Women in the Nineteenth Century American Novel, Oxford University Press, New York 1976, s. 257). Według Elizabeth Nolan, dzięki odrzuceniu wszelkich kompromisów, Edna „osiąga swego rodzaju transcendencję” (dz. cyt., s. 128). Mary Papke przyznaje, że śmierć Edny to „niewypowiedziana tragedia”, lecz znaczenie dzieła Chopin polega na ukazaniu wizji świata, gdzie „kobiece doświadczenia i potrzeby nie są już wymazywane lub spychane na margines, ale zajmują centralne miejsce" (dz. cyt., s. 73). Elaine Showalter przypomina, że czytelnicy ostatniej dekady XIX wieku byli przyzwyczajeni do tego, aby utonięcie interpretować jako karę za kobiecą transgresję przeciw moralności (Tradition and the Female Talent: The Awakening as a Solitary Book, w: Kate Chopin..., s. 22-23). Martha Fodaski Black twierdzi, że samobójcza śmierć Edny to „deklaracja zarówno wolności, jak i rozpaczy” (The Quintessence of Chopinism, w: Kate Chopin..., s. 113). Interpretacja, która wydaje mi się najciekawsza to przywołany już wcześniej artykuł Jeffreya Bermana Romanticizing Edna’s Suicide. Według autora należy zwrócić większą uwagę na celowe „uromantycznienie” i wyidealizowanie samobójstwa Edny. Zarówno styl końcowych akapitów powieści, jak i banalna postromantyczna metaforyka, mają budzić jedynie pozytywne konotacje. Jak pisze Berman: „Chopin opisuje Ednę całkowicie panującą nad swym losem, cudownie zestrojoną z widokami i dźwiękami morza, lecz gotową to wszystko poświęcić, aby osiągnąć ostateczną, transcendentną jedność z morzem. Podaje nam się tutaj wyidealizowany obraz samobójstwa, pozbawiony przemocy i strachu" (s. 59). Berman zwraca również uwagę na enigmatyczność opisu śmierci, który pomija wszelkie elementy mogące tę romantyczną wizję zakłócić. Są również krytycy, którzy kwestionują odczytanie ostatnich akapitów powieści jako opisu samobójstwa; zob. na przykład: Robert Treu, Surviving Edna: A Reading of the Ending of The Awakening, „College Literature”, t. 27, nr 2, wiosna 2000, s. 21-36. 
wszelkie świętości, aby móc się w nim całkowicie zanurzyć. Aż do samego końca nie uświadamia sobie ciężaru swoich czynów, chyba że za spóźniony wyraz samoświadomości należy uznać scenę, w której leżąc na łożu śmierci, prosi o lustro i wybucha płaczem. W przypadku Edny z kolei widzimy pewną ewolucję; jej przebudzenie odbywa się na wielu poziomach i jednym $\mathrm{z}$ nich jest filozoficzne uświadomienie sobie, że możliwość osiągnięcia całkowitego wyzwolenia jest jedynie piękną mrzonką. Emma nie potrafi żyć bez mężczyzny, którego obsadza w roli księcia fantastycznego romansu, w jaki próbuje zmienić swoje życie. Edna oczywiście pragnie Roberta i jego nagłe zniknięcie jest dla niej przykrą niespodzianką, ale jednocześnie na krótko przed śmiercią uświadamia sobie, że „przyjdzie taki dzień, kiedy również i on, i myśl o nim zniknie z jej życia, pozostawiając pustkę i samotność" ${ }^{39}$. Stąd już blisko do zdania sobie sprawy, iż absolutna autonomia tak naprawdę oznacza absolutną samotność. Jak pisze Lawrence Thornton, w przeciwieństwie do Flauberta, „Chopin pozwala swojej bohaterce na przynajmniej częściowe zrozumienie kłamstwa, które kształtuje jej wyobrażenia [o życiu]"’40.

Zresztą stosunek do samotności również dzieli obie bohaterki. Emma samotności nie znosi i wypełnia ją towarzystwem albo lekturą romansów. Edna również pragnie towarzystwa, ale jednocześnie możliwość samotności staje się dla niej gwarancją niezależności i podstawą emancypacji. Poprzez porzucenie domu męża i przenosiny do skromnego "gołębnika” Edna nie tylko walczy o możliwość zawarcia związku z innym mężczyzną, ale również przyznaje sobie prawo do bycia w samotności ${ }^{41}$. Jednak podobnie do Emmy Bovary, Edna jest całkowicie skoncentrowana na sobie, na swoich oczekiwaniach i potrzebach. Również w jej wypadku raz wprawiona w ruch potrzeba realizacji swoich pragnień nie może się zatrzymać, odrzucając wszelkie ograniczenia i zakazy.

Na zakończenie chciałbym przywołać pouczającą opowieść Bernarda Koloski, jednego z najwybitniejszych znawców dzieła Kate Chopin. Trafił on do Polski jako stypendysta Fullbrighta w ciemnych czasach stanu wojennego. Podczas zajęć poprosił polskich studentów o przeczytanie Przebudzenia, mając nadzieję, że lektura i dyskusja rozproszą nieco duszną atmosferę tamtych dni, jednak doświadczenia amerykańskiej damy z końca XIX wieku, mieszkającej w Luizjanie i otoczonej przez służących oraz adoratorów, były tak odległe od przeraźliwie zgrzebnej rzeczywistości Polski początku lat osiemdziesiątych, że studenci nie potrafili z siebie wykrzesać zbyt wiele współczucia dla głównej bohaterki. Jak wyznała jedna

39 K. Chopin, Przebudzenie, s. 133.

40 Lawrence Thornton, The Awakening: A Political Romance, w: "American Literature," nr 52.1 (1980), s. 51.

41 Elaine Showalter dodaje, „Rzeczywiście, Przebudzenie, które pierwotnie nosiło podtytuł Samotna dusza można odczytać jako opis ewolucji Edny Pontellier, która wiedzie od romantycznych fantazji o zjednoczeniu z inną osobą do samostanowienia i samowystarczalności” (dz. cyt., s. 16). 
studentka: „Problem z Edną polega na tym, że nie wie, co to znaczy stać w kolejce po chleb"42. Inna oświadczyła:

Nie potrafię sobie nawet wyobrazić, jak to jest być Edną Pontellier. Mieszkać we własnym domu, mieć kogoś do opieki nad dzieckiem, siedzieć na plaży albo malować obrazy, chodzić na wyścigi konne albo urządzać przyjęcia ... i mieć męża, który zarabia tyle, że nie tylko starcza na rachunki, ale nawet przysyła mi słodycze. Po prostu nie potrafię sobie tego wyobrazić ${ }^{43}$.

Pozostaje mieć nadzieję, że trzydzieści pięć lat później Edna Pontellier nie jest już dla polskiego czytelnika tak obcą i niezrozumiałą postacią.

\section{Bibliografia}

Arnavon Cyrille, Introduction to Kate Chopin, Edna (1953), tłum. Bjorn Braaten, Emily Toth, w: The Kate Chopin Miscellany, red. Per Seyersted, Emily Toth, Northwestern University Press, Natchitoches, LA 1979, s. 168-188.

Beer Janet, Nolan Elisabeth (red.), The Awakening: Sourcebook, Routledge, London 2007.

Beer Janet (red.), The Cambridge Companion to Kate Chopin, Cambridge University Press, Cambridge 2008.

Berman Jeffrey, Romanticizing Suicide in Kate Chopin's “Awakening”, w: Surviving Literary Suicide, University of Massachusetts Press, Amherst 1999, s. 46-66.

Black Martha Fodaski, The Quintessence of Chopinism, w: Kate Chopin, red. H. Bloom, s. $103-118$.

Bonner Thomas, The Kate Chopin Companion, Santa Barbara, Greenwood 1988.

Chopin Kate, Przebudzenie, tłum. Ariadna Demkowska-Bohdziewicz, Libros, Warszawa 2002.

Chopin Kate, The Awakening, Norton Critical Editions, red. Margo Culley, W.W. Norton \& Company, New York 1993.

Ewell Barbara C., Kate Chopin, Ungar Publishing Company, New York 1986.

Fryer Judith, The Faces of Eve: Women in the Nineteenth Century American Novel, Oxford University Press, New York 1976.

Fusco Richard, Maupassant and the American Short Story: The Influence of Form at the Turn of the Century, Pennsylvania State University Press, University Park, PA 1994.

42 Koloski, dz. cyt., s. 190.

43 Koloski, dz. cyt., s. 190. 
Heath Stephen, Chopin's Parrot, “Textual Practice”, wiosna 1994, nr 8 (1), s. 11-32.

Heilmann Ann, The Awakening and New Woman fiction, w: The Cambridge Companion to Kate Chopin, s. 87-104.

Bloom Harold (red.), Kate Chopin, Chelsea House Publications, New York 2007.

Koloski Bernard (red.), Awakenings. The Story of the Kate Chopin Revival, Louisiana State University Press, Baton Rouge 2009.

Koloski Bernard, Kate Chopin: A Study of the Short Fiction, Twayne Publishers, Woodbridge 1996.

Koloski Bernard, The Awakening. The first 100 years, w: The Cambridge Companion to Kate Chopin, s. 161-173.

Mazan Bogdan, Literackie transpozycje doświadczenia bowarystowskiego w miłości, w: Sztuka a erotyka, red. Teresa Hrankowska, Stowarzyszenie Historyków Sztuki, Warszawa 1995, s. 35-47.

Mazur Aneta, Nowelistyczny tryptyk Stefanii Chłędowskiej - zagubione ogniwo polskiego „bowaryzmu”? „Pamiętnik Literacki” 2012, nr 4, s. 27-44.

Nolan Elizabeth, The Awakening as literary innovation: Chopin, Maupassant and the evolution of genre, w: The Cambridge Companion to Kate Chopin, s. 118-131.

Papke Mary E. Kate Chopin's Social Fiction, w: Kate Chopin, red. Harold Bloom, Chelsea House Publishers, Langhorne 2007, s. 27-74.

Pollard Percival, Their Day in Court, Neale, New York 1909.

Rosowski Susan J., The Novel of Awakening, "Genre” 1979, nr 12, s. 313-332.

Seyersted Per, Kate Chopin: A Critical Biography, Louisiana State University Press, Baton Rouge 1980.

Showalter Elaine, Tradition and the Female Talent: The Awakening as a Solitary Book, w: Kate Chopin, red. H. Bloom, s. 22-23.

Skaggs Peggy, Kate Chopin, Twayne Publishers, Woodbridge 1985.

The Awakening: Complete, Authoritative Text With Biographical \& Historical Contexts, Critical History, \& Essays from Five Contemporary Critical Perspectives, red., Walker Nancy Bedford/St Martins, Boston 1993.

The Awakening: Some Contemporary Responses [online], http://www.people.virginia. edu/ sfr/enam854/summer/awcritf.html [dostęp 20.08.2017].

Thornton Lawrence, The Awakening: A Political Romance, "American Literature" 1980, nr 52.1, s. 50-66.

Toth Emily, What we do and don't know about Chopin's life, w: The Cambridge Companion to Kate Chopin, s. 13-26.

Treu Robert, Surviving Edna: A Reading of the Ending of The Awakening, „College Literature", wiosna 2000, nr 27.2, s. 21-36.

Walker, Nancy, A Critical History of The Awakening, w: Kate Chopin. The Awakening, s. 141-157. 
Wheeler Kathleen, Kate Chopin: Ironist of Realism, w: Kate Chopin, red. H. Bloom, s. 119-144.

Witherow Jean, "Abysses of Solitude": Chopin's Intertextuality with Flaubert, "The Mississippi Quarterly", wiosna 2011, nr 64.1-2, s. 87-107.

Przemysław Michalski

\title{
Is Kate Chopin's The Awakening the American Madame Bovary?
}

\author{
Summary
}

This article deals with the question of the so-called Bovarism in The Awakening, the famous novel written by Kate Chopin. When it was first published in 1899, it was universally condemned for its alleged obscenity, just like its French predecessor. It is true, however, that unlike Flaubert's book, The Awakening did not find itself in the dock, faced with charges of immorality, but the hostile reviews condemned the novel to many decades of obscurity. In this article, I try to return to the question of parallels between the two novels, which can be seen on many levels. Some similarities concern both male and female characters, while others are to do with specific narrative decisions and solutions. The most conspicuous example of the latter is the suicidal death of both heroines.

Keywords: Chopin; Flaubert; bovarism; novel; awakening; suicide

Dr hab. Przemysław Michalski, prof. UP - studiował w Instytucie Filologii Angielskiej Uniwersytetu Jagiellońskiego, gdzie w roku 1996 uzyskał tytuł magistra. Tematem jego pracy magisterskiej były związki pomiędzy Kierkegaardowskim pojęciem rozpaczy oraz poezją T.S. Eliota. W roku 2005 obronił na Uniwersytecie Jagiellońskim pracę doktorską, która dotyczyła problemu obecności elementów mistycznych w poezji G.M. Hopkinsa. W roku 2016 uzyskał tytuł doktora habilitowanego na podstawie rozprawy pt. „No friendly God?” (Self-)Manifestations of the Divine in the Poetry of R.S. Thomas. Obecnie zajmuje stanowisko adiunkta w Instytucie Neofilologii Uniwersytetu Pedagogicznego im. KEN w Krakowie. Opublikował szereg artykułów naukowych na temat poezji anglojęzycznej oraz polskiej, jak również związków między literaturą, filozofią i religią. 